\title{
USING LINE $\times$ TESTER METHOD AND HETEROTIC GROUPING TO SELECT HIGH YIELDING GENOTYPES OF BREAD WHEAT (Triticum aestivum $\mathrm{L}$.)
}

\author{
Imren KUTLU ${ }^{1^{*}}$, Zeynep SIREL ${ }^{2}$ \\ ${ }^{1}$ Eskisehir Osmangazi University, Faculty of Agriculture, Department of Biosystem Engineering, \\ Eskisehir, TURKEY \\ ${ }^{2}$ Transitional Zone Agricultural Research Institute, Eskisehir, TURKEY \\ *Corresponding author: ikutlu@ogu.edu.tr
}

Received: 18.02.2019

\begin{abstract}
Studies on genetic gain, made by direct or indirect phenotypic selection, are needed regularly since they offer valuable information for breeding programs. The purpose of this study to investigate the gene effects on the yield-related traits of the $F_{1}$ and $F_{2}$ populations of bread wheat "linextester" crosses; to identify suitable parents and promising hybrids for development of high yielding varieties; to determine correlations between genetic distances of the parents and heterosis with heterotic groups (HG) based on specific combining ability (SCA). The combining abilities, heritability, heterosis (Ht)-heterobeltiosis ( $\mathrm{Hb}$ ) and the potential of populations as a HG were analysed. According to the results, non-additive gene effects were predominated and narrow sense heritability was low for all examined features, significant combining ability effects were determined for some parents and hybrids. While DH18, DH20 and Harmankaya-99 were good combiners, "DH16×Altay-2000", "DH16×Kate A-1" and "DH21×Kate A-1" were promising hybrids. The yield, Ht and SCA were higher in inter-group hybrids than intra-group hybrids in HG. Although molecular markers are considered more reliable to create HG, only marker selection will not adequate to improve the trait in question because of complex genetic structure and environmental influence. Therefore, HG based on yield-specific SCA can be utilized as a reliable parameter in breeding studies.
\end{abstract}

Keywords: Combining ability, cluster analyses, heterosis, heritability, morphological markers, yield component

\section{INTRODUCTION}

Wheat is a leading cereal crop with strategic importance in terms of production quantity and harvested area, due to be highly adaptable at unfavourable conditions, grown easy and machine based, used commonly for human nutrition. Changing of yield potential due to the climatic change and quickly decreased genetic potential make the continuity of wheat breeding studies important (Kutlu and Olgun, 2015). The breeders are still continuing the quest for varieties which their yield and quality are high and stable, resistant to biotic (diseases and pests) and abiotic (high temperature, cold, drought and salinity) stresses.

Progress in terms of complex heredity characters such as grain yield and its components can be achieved only by knowing the genetic structure of these properties. Increasing yield is possible with improving yield components such as number of fertile spike, grain number and weight per spike (Aytac and Kinaci, 2009). Recent studies have shown that the use of physiological characteristics such as stoma conductivity, photosynthesis rate, membrane thermo-stability, canopy temperature and chlorophyll content as a selection criterion can improve wheat yield (Yildirim et al., 2009; Rad et al., 2012; Hannachi et al., 2013; Yildirim et al., 2013; Singh et al., 2017; Beena et al., 2018). Physiological characteristics such as canopy temperature and leaf chlorophyll content are important for drought and high temperature resistance studies due to the fact that they can be detected easily and rapidly, as well as having high positive correlations with yield (Reynolds et al., 2001). In addition to the relations with the mentioned features, the flag leaf area where the most photosynthetic activity is realized compared to the other leaves is also accented in breeding studies (Flood et al., 2011).

Knowledge on the genetic structure that manage physiological characters and yield is important to determine the breeding methodology for developing new varieties. The dominant gene effect help develop hybrid plants while the additive gene effect provide the progress by selection in terms of a character (Hill, 2010). The specific combining ability (SCA) is reflecting the effect of 
dominant and epistatic genes and it is the superiority of the hybrid between two genotypes, while the general combining ability (GCA) defined as the superiority of a genotype in a hybridization series is high in the properties under additive gene effect. Parents with high GCA and distant genetic architecture produce higher-value hybrids (Krystkowiak et al., 2009). "Line $\times$ tester" analysis is used in order to determine the GCA and SCA. The genetic distance is successfully defined by multivariate clustering analysis called heterotic grouping (Acquaah, 2012). Heterotic groups (HG) classify germplasm groups genetically distinct and they produce superior hybrids when hybridized. Hybrids of different $\mathrm{HG}$ will increase heterozygosity, heterosis $(\mathrm{Ht})$ and yield stability of new varieties (Fan et al., 2009). Genetic diversity among parents is important for the success of a breeding program that will largely determine the magnitude of $\mathrm{Ht}$ in $\mathrm{F}_{1}$ hybrids (Tecklewold and Becker, 2006). Heterosis indicates a significant relationship with the combining ability of parents constitutes hybrids. Breeders should classify all parental lines within few $\mathrm{HG}$ as possible because numerous $\mathrm{HG}$ will be required more hybridization between groups and breeding efficiency will be reduced. Heterotic grouping based on genetic distances and SCA is useful for identifying parents that will produce superior hybrids without making all possible hybrids among the selected parents (Riday et al., 2003).

The purpose of this study was to estimate the GCA and SCA, heritability degrees and gene actions of the yield and yield-related characteristics in $F_{1}$ and $F_{2}$ generations of "line $\times$ tester" hybrids. In addition, determination of correlations between genetic distance and $\mathrm{Ht}$ of grouped parents in HG based on SCA, and appropriate parents and promising hybrids was aimed.

\section{MATERIALS AND METHODS}

Seven doubled haploid (DH) bread wheat line with different plant characteristic were used as female (line), and four registered varieties (Altay-2000, Bezostaja-1, Harmankaya-99, Kate A-1) as male (tester) and they crossed according to "line $\times$ tester" matting design. Doubled haploid lines were obtained from $\mathrm{F}_{2}$ generations of hybrids between 33IBSWN-S-244, Tosunbey and Mufitbey. The testers are well-adapted genotypes to Central Anatolian conditions. They also have different characteristic such as maturity time, flag leaves characteristic, chlorophyll content and spike characteristics.

The experimental field with low organic matter (1.2\%) and moderate lime $(9.6 \%)$. It was non-saline and slightly alkaline ( $\mathrm{pH}$ 7.9-8.3). The texture class of soil was clay. The total precipitation during the experiment year was $337.9 \mathrm{~mm}$, the average temperature was $8.47^{\circ} \mathrm{C}$ and the average humidity was $73.3 \%$.

The 28 genotypes belong to $F_{1}$ and $F_{2}$ generations of "line $\times$ tester" bread wheat crosses and their 11 parents were grown in a randomized complete block design with three replications at Eskisehir Osmangazi University, Faculty of Agriculture research areas in 2016-2017 growing season. The plots consisted of four rows had $1 \mathrm{~m}$ long, there were 20 plants in each row and row spacing was $30 \mathrm{~cm}$. Standard practices (irrigation, fertilization etc.) used by the breeding programs were applied. $60 \mathrm{~kg} \mathrm{~N}$ $\mathrm{ha}^{-1}$ and $60 \mathrm{~kg} \mathrm{P}_{2} \mathrm{O}_{5} \mathrm{ha}^{-1}$ fertilizer were applied at sowing time and $60 \mathrm{~kg} \mathrm{~N} \mathrm{ha}^{-1}$ at the stem elongation period.

Yield, yield components and some physiological plant characters such as flag leaf chlorophyll content and canopy temperature were measured in parents, $F_{1}$ and $F_{2}$ hybrid plants. Flag leaf area was determined according to method described by Kalayci et al. (1998). Flag leaf chlorophyll content was measured using a chlorophyll meter named "Spectrum Field Scout CM 1000" at heading stage (Wenkel et al., 2003). To measure the canopy temperature was used an infrared thermometer (Jackson et al., 1996). Grain yield was determined as grams in harvested crops from each plot. Other measurements for plant height $(\mathrm{cm})$, spike length $(\mathrm{cm})$, spike weight $(\mathrm{g})$, number of kernel per spike, kernel weight per spike $(\mathrm{g})$ and spike harvest index (\%) were recorded on ten random plant samples taken from each plot.

"Line×tester" analyses as described by Kempthrone (1957) was performed by the TarPopGen Statistical Package Program developed by Ozcan and Acikgoz (1999). The analysis of variance, GCA, SCA, variance of additive and dominant gene effects based on variances of GCA and SCA and broad $\left(\mathrm{H}^{2}\right)$ and narrow sense $\left(\mathrm{h}^{2}\right)$ heritability were estimated according to Falconer and Mackay (1996). Heterosis (Ht) and heterobeltiosis (Hb) values and their statistical significance (Cochran and Cox, 1957; Fonseca and Peterson, 1968) were calculated with the formulation created in the EXCEL computer program. Heterotic grouping and cluster analysis were performed using the method proposed Anderberg (1993) in IBM SPSS 20 package program.

\section{RESULTS AND DISCUSSION}

\section{Line $\times$ tester variance analyses and estimations of genetic components}

The "line $\times$ tester" variance analysis results of parents and hybrid combinations are given at the Table 1 for examined traits. The mean squares of all genotypes (treatment) were significant, also the parents and crosses showed significant variation for most of traits. This variation indicated that examined genotypes had different genetic background. The interaction of parents and crosses was significant for all character except for flag leaf area and canopy temperature in $\mathrm{F}_{2}$ and this significancy pointed out the performance of hybrids was different than their parents and there was a wide range $\mathrm{Ht}$ among the crosses for examined traits. The significant variation of lines and testers changing according to trait or generation suggested difference of contribution of lines or testers towards GCA variance components. The significant mean squares of "line $\times$ tester" interaction for most of the characters revealed the significant contribution of hybrids for SCA variance components and the contributions of testers were found the close to lines generally. Variable significant variance according to trait or generation 
expressed that lines had different ranking according to the performance of their hybrids with the four testers. Similar findings was found most of the researchers who studied "line×tester" analysis (Abdel Nour et al., 2011; Aslam et al., 2014; Barot et al., 2014).

Table 1. Line $\mathrm{x}$ tester variance analyses for examined traits.

\begin{tabular}{|c|c|c|c|c|c|c|c|c|c|c|c|}
\hline \multirow[t]{2}{*}{ SOV } & \multirow[t]{2}{*}{ DF } & \multicolumn{2}{|c|}{ FLA } & \multicolumn{2}{|c|}{ FLCC } & \multicolumn{2}{|c|}{ CT } & \multicolumn{2}{|c|}{$\mathbf{P H}$} & \multicolumn{2}{|c|}{ SL } \\
\hline & & $\mathbf{F}_{1}$ & $\mathbf{F}_{2}$ & $\mathbf{F}_{1}$ & $\mathbf{F}_{2}$ & $F_{1}$ & $\mathbf{F}_{2}$ & $\mathbf{F}_{1}$ & $\mathbf{F}_{2}$ & $\mathbf{F}_{1}$ & $F_{2}$ \\
\hline Replication & 2 & $23.44^{\mathrm{ns}}$ & $0.15^{\mathrm{ns}}$ & $910.87^{\mathrm{ns}}$ & $1315.65^{\mathrm{ns}}$ & $0.07^{\mathrm{ns}}$ & $0.41^{* *}$ & $1.98^{\mathrm{ns}}$ & $44.50^{\mathrm{ns}}$ & $0.10^{*}$ & $0.26^{\mathrm{ns}}$ \\
\hline Treatment & 38 & $65.36^{* *}$ & $36.89^{*}$ & $3729.65^{*}$ & $11370.63^{* *}$ & $2.85^{* *}$ & $0.34^{* *}$ & $216.09^{* *}$ & $180.62^{* *}$ & $0.92^{* *}$ & $0.99^{* *}$ \\
\hline Parents & 10 & $43.87^{\mathrm{ns}}$ & $34.24^{\mathrm{ns}}$ & $5606.89^{*}$ & $2615.08^{*}$ & $2.39^{* *}$ & $0.26^{* *}$ & $308.19^{* *}$ & $343.52^{* *}$ & $1.18^{\text {** }}$ & $0.90^{* *}$ \\
\hline Interaction & 1 & $208.03^{* *}$ & $69.19^{\mathrm{ns}}$ & $32696.69^{* *}$ & $37964.81^{* *}$ & $2.21^{*}$ & $0.01^{\mathrm{ns}}$ & $1247.41^{\text {** }}$ & $396.71^{* *}$ & $8.88^{\text {** }}$ & $6.05^{* *}$ \\
\hline Crosses & 27 & $68.03^{* *}$ & $36.68^{*}$ & $1961.53^{\mathrm{ns}}$ & $13628.46^{* *}$ & $3.04^{* *}$ & $0.38^{* *}$ & $143.78^{* *}$ & $112.29^{* *}$ & $0.53^{* *}$ & $0.83^{* *}$ \\
\hline Lines & 6 & $55.94^{\mathrm{ns}}$ & $41.31^{\mathrm{ns}}$ & $3176.15^{\mathrm{ns}}$ & $11122.63^{\mathrm{ns}}$ & $1.79^{\mathrm{ns}}$ & $1.05^{* *}$ & $305.55^{*}$ & $244.64^{* *}$ & $1.06^{*}$ & $2.11^{* *}$ \\
\hline Testers & 3 & $112.36^{\mathrm{ns}}$ & $65.61^{\mathrm{ns}}$ & $3570.27^{\mathrm{ns}}$ & $11888.91^{\mathrm{ns}}$ & $6.62^{\mathrm{ns}}$ & $0.50^{*}$ & $147.68^{\mathrm{ns}}$ & $349.50^{* *}$ & $0.46^{\mathrm{ns}}$ & $0.23^{\mathrm{ns}}$ \\
\hline Line $\times$ Tester & 18 & $64.67^{* *}$ & $30.32^{\mathrm{ns}}$ & $1288.53^{\mathrm{ns}}$ & $14753.67^{* *}$ & $2.87^{* *}$ & $0.13^{* *}$ & $89.20^{* *}$ & $28.64^{\mathrm{ns}}$ & $0.37^{\text {** }}$ & $0.50^{*}$ \\
\hline Error & 76 & 23.25 & 21.38 & 2196.27 & 1145.15 & 0.33 & 0.03 & 2.55 & 21.45 & 0.03 & 0.27 \\
\hline \multicolumn{12}{|l|}{ GC } \\
\hline$\sigma^{2} \mathrm{GCA} / \sigma^{2} \mathrm{SCA}$ & & 0.01 & 0.05 & -0.05 & -0.01 & 0.005 & 0.14 & 0.04 & 0.78 & 0.04 & 0.09 \\
\hline$\sigma^{2} \mathrm{~A}$ & & 0.15 & 0.14 & 29.91 & -50.01 & 0.008 & 0.01 & 2.43 & 3.72 & 0.01 & 0.01 \\
\hline$\sigma^{2} \mathrm{D}$ & & 13.81 & 2.98 & -302.58 & 4536.17 & 0.84 & 0.04 & 28.88 & 2.39 & 0.11 & 0.08 \\
\hline $\mathrm{H}^{2}$ & & 0.47 & 0.27 & 0.29 & 0.82 & 0.79 & 0.86 & 0.98 & 0.79 & 0.94 & 0.56 \\
\hline$h^{2}$ & & 0.004 & 0.006 & 0.02 & -0.01 & 0.01 & 0.13 & 0.07 & 0.13 & 0.04 & 0.04 \\
\hline $\operatorname{CLV}(\%)$ & & 18.27 & 25.03 & 35.98 & 18.14 & 13.06 & 61.56 & 47.23 & 48.41 & 44.34 & 56.43 \\
\hline CTV (\%) & & 18.35 & 19.87 & 20.22 & 9.69 & 24.15 & 14.72 & 11.41 & 34.58 & 9.64 & 3.09 \\
\hline $\mathrm{CL} \times \mathrm{TV}(\%)$ & & 63.37 & 56.00 & 43.79 & 72.17 & 62.79 & 23.72 & 41.36 & 17.01 & 46.02 & 40.48 \\
\hline
\end{tabular}

\begin{tabular}{|c|c|c|c|c|c|c|c|c|c|c|c|}
\hline \multirow[t]{2}{*}{ SOV } & \multirow[t]{2}{*}{ DF } & \multicolumn{2}{|c|}{ SW } & \multicolumn{2}{|c|}{ KNS } & \multicolumn{2}{|c|}{ KWS } & \multicolumn{2}{|c|}{ SHI } & \multicolumn{2}{|c|}{ GY } \\
\hline & & $\mathbf{F}_{1}$ & $\mathbf{F}_{2}$ & $\mathbf{F}_{1}$ & $\mathbf{F}_{2}$ & $F_{1}$ & $F_{2}$ & $F_{1}$ & $\mathbf{F}_{2}$ & $\mathbf{F}_{1}$ & $\mathbf{F}_{2}$ \\
\hline Replication & 2 & $0.00^{\mathrm{ns}}$ & $0.11^{\mathrm{ns}}$ & $0.40^{\mathrm{ns}}$ & $57.28^{\mathrm{ns}}$ & $0.004^{\mathrm{ns}}$ & $0.02^{\mathrm{ns}}$ & $1.53^{\mathrm{ns}}$ & $21.94^{\mathrm{ns}}$ & $395.12^{\mathrm{ns}}$ & $644.79^{\text {ns }}$ \\
\hline Treatment & 38 & $0.39^{* *}$ & $0.16^{* *}$ & $135.92^{* *}$ & $65.93^{* *}$ & $0.30^{* *}$ & $0.09^{* *}$ & $36.78^{* *}$ & $38.59^{* *}$ & $16853.85^{* *}$ & $13044.54^{* *}$ \\
\hline Parents & 10 & $0.26^{* *}$ & $0.28^{* *}$ & $106.46^{\text {** }}$ & $119.56^{* *}$ & $0.21^{\text {** }}$ & $0.11^{* *}$ & $40.10^{* *}$ & $116.71^{* *}$ & $9859.91^{* *}$ & $8721.96^{* *}$ \\
\hline Interaction & 1 & $3.75^{* *}$ & $0.09^{\text {ns }}$ & $788.57^{\text {*** }}$ & $277.99^{* *}$ & $3.22^{* *}$ & $0.01^{\mathrm{ns}}$ & $259.31^{* *}$ & $2.12^{\text {ns }}$ & $55360.29^{* *}$ & $50898.12^{* *}$ \\
\hline Crosses & 27 & $0.31^{* *}$ & $0.12^{* *}$ & $122.66^{* *}$ & $38.22^{* *}$ & $0.23^{* *}$ & $0.08^{* *}$ & $27.31^{* *}$ & $11.01^{\mathrm{ns}}$ & $18018.03^{* *}$ & $13243.51^{* *}$ \\
\hline Lines & 6 & $0.64^{*}$ & $0.11^{\mathrm{ns}}$ & $274.16^{*}$ & $54.39^{\mathrm{ns}}$ & $0.52^{* *}$ & $0.07^{\mathrm{ns}}$ & $48.47^{*}$ & $6.38^{\mathrm{ns}}$ & $41003.66^{* *}$ & $12335.62^{\mathrm{ns}}$ \\
\hline Testers & 3 & $0.48^{\mathrm{ns}}$ & $0.34^{*}$ & $137.50^{\mathrm{ns}}$ & $70.03^{\mathrm{ns}}$ & $0.40^{*}$ & $0.20^{\mathrm{ns}}$ & $58.45^{*}$ & $31.70^{*}$ & $31790.38^{*}$ & $24723.98^{\mathrm{ns}}$ \\
\hline Line $\times$ Tester & 18 & $0.17^{* *}$ & $0.09^{\text {ns }}$ & $69.69^{* *}$ & $27.52^{\mathrm{ns}}$ & $0.10^{* *}$ & $0.07^{*}$ & $15.07^{* *}$ & $9.10^{\mathrm{ns}}$ & $8060.77^{* *}$ & $11632.72^{* *}$ \\
\hline Error & 76 & 0.01 & 0.05 & 1.14 & 18.66 & 0.004 & 0.03 & 3.58 & 10.27 & 376.26 & 2175.77 \\
\hline \multicolumn{12}{|l|}{ GC } \\
\hline$\sigma^{2} \mathrm{GCA} / \sigma^{2} \mathrm{SCA}$ & & 0.05 & 0.08 & 0.05 & 0.08 & 0.09 & 0.00 & 0.07 & -0.11 & 0.09 & 0.01 \\
\hline$\sigma^{2} \mathrm{~A}$ & & 0.01 & 0.001 & 2.35 & 0.47 & 0.01 & 0.001 & 0.54 & 0.08 & 442.54 & 71.59 \\
\hline$\sigma^{2} \mathrm{D}$ & & 0.06 & 0.012 & 22.85 & 2.95 & 0.03 & 0.011 & 3.83 & -0.39 & 2561.50 & 3152.32 \\
\hline $\mathrm{H}^{2}$ & & 0.97 & 0.50 & 0.98 & 0.56 & 0.97 & 0.46 & 0.82 & 0.58 & 0.96 & 0.71 \\
\hline$h^{2}$ & & 0.06 & 0.01 & 0.09 & 0.02 & 0.14 & 0.02 & 0.07 & 0.01 & 0.13 & 0.01 \\
\hline $\operatorname{CLV}(\%)$ & & 45.75 & 19.42 & 49.67 & 31.62 & 50.57 & 19.42 & 39.44 & 12.87 & 50.57 & 20.70 \\
\hline CTV (\%) & & 17.06 & 31.01 & 12.46 & 20.36 & 19.60 & 31.10 & 23.78 & 31.99 & 19.60 & 20.74 \\
\hline $\mathrm{CL} \times \mathrm{TV}(\%)$ & & 37.19 & 49.57 & 37.88 & 48.01 & 29.82 & 49.57 & 36.78 & 55.13 & 29.82 & 58.56 \\
\hline
\end{tabular}

${ }^{*} \mathrm{P}<0.05,{ }^{* * *} \mathrm{P}<0.01$ (SOV: Source of variation; DF: Degree of freedom; FLA: Flag leaf area; FLCC: Flag leaf chlorophyll content; CT: Canopy temperature; PH: Plant height; SL: Spike length; SW: Spike weight; KNS: Kernel number per spike; KWS: Kernel weight per spike; SHI: Spike harvest index; GY: Grain yield; GC: Genetic components; GCA: General combining ability; SCA: Specific combining ability; A: additive; D: Dominance; $\mathrm{H}^{2}$ : Broad sense heritability; $\mathrm{h}^{2}$ : Narrow sense heritability; CLV: Contribution of lines variance; CTV: Contribution of testers variance; $\mathrm{CL} \times \mathrm{TV}$ : Contribution of line $\times$ tester interaction variance)

When the estimates of genetic variance of the studied traits were examined (Table 1), the ratio of $\sigma^{2} \mathrm{GCA} /$ $\sigma^{2} \mathrm{SCA}$ for all traits was smaller than one in both generations, indicating non-additive gene effects play a role in the heredity or expression of these traits. Dominance variance was greater than additive variance for all traits, indicating a superior dominance in non- additive gene effects. The features associated with yield have a quantitative inheritance, and therefore gene expression of these properties may be different in various environments. The $\mathrm{H}^{2}$ degrees of the yield and its components were found generally high although the $h^{2}$ was very low. The reasons of a very high differences between the in the $\mathrm{H}^{2}$ and $\mathrm{h}^{2}$ are the dominant and 
epistatic variance in total genetic variance is quite large from the additive variance. Non-additive effects can be superior due to a high degree of dispersion of increasing alleles between parents. Dominance, one component of non-additive genetic variance, is a fundamental cause of inbreeding depression while epistasis appears depending on the genetic background and environmental conditions (Goldringer et al., 1997; Novoselovic et al., 2004). The selection should be delayed to following generations in this population. Similar results were detected by other researchers and they also suggested that waiting to next generations for selection if there were low $h^{2}$ and dominant gene effects (Istipliler et al., 2015; Saeed et al., 2016; Saeed and Khalil, 2017).

\section{Performances of parents and general combining ability}

When the average values of the parents were examined, it was shown that Bezostaja-1 appears to be the best-performing parent for flag leaf area, canopy temperature and spike harvest index. DH21 for flag leaf chlorophyll content, DH19 for plant height and grain yield, DH21 for spike length, DH6 for spike weight and kernel number per spike, and Harmankaya-99 for kernel weight per spike were the other remarkable genotypes (Table 2).

Table 2. Mean performance and general combining ability effects of parents for yield-related characteristics.

\begin{tabular}{|c|c|c|c|c|c|c|c|c|c|c|c|}
\hline Lines & & FLA & FLCC & CT & PH & SL & SW & KNS & KWS & SHI & GY \\
\hline \multirow{3}{*}{ DH6 } & Mean & 23.52 & 566.34 & 18.10 & 92.34 & 10.75 & 3.12 & 53.85 & 2.19 & 70.30 & 601.05 \\
\hline & $\mathrm{F}_{1}$ & -0.8 & 21.83 & -0.23 & $-6.88^{* *}$ & $0.25^{* *}$ & $0.39^{* * *}$ & $8.73^{* *}$ & $0.34^{* *}$ & $1.95^{\text {** }}$ & $94.03^{* *}$ \\
\hline & $\mathrm{F}_{2}$ & 1.13 & 0.7 & $0.45^{* *}$ & $-3.26^{* *}$ & -0.06 & -0.01 & -0.03 & -0.02 & -0.39 & -21.35 \\
\hline \multirow{3}{*}{ DH16 } & Mean & 29.97 & 521.72 & 18.73 & 111.02 & 9.20 & 2.43 & 37.07 & 1.71 & 70.54 & 557.75 \\
\hline & $\mathrm{F}_{1}$ & $4.22^{* *}$ & 15.17 & -0.29 & 0.72 & $-0.47^{* *}$ & $-0.30^{* *}$ & $-3.65^{* *}$ & $-0.22^{* *}$ & -0.02 & $-60.47^{* *}$ \\
\hline & $\mathrm{F}_{2}$ & 2.34 & -7.85 & $0.41^{* *}$ & $4.79^{* *}$ & $-0.75^{* *}$ & $-0.15^{*}$ & $-3.19^{*}$ & $-0.12^{*}$ & -0.26 & $-37.01^{* *}$ \\
\hline \multirow{3}{*}{ DH18 } & Mean & 27.60 & 520.50 & 17.94 & 80.45 & 10.82 & 2.74 & 42.52 & 1.82 & 66.44 & 608.96 \\
\hline & $\mathrm{F}_{1}$ & 0.09 & 10.42 & $0.35^{*}$ & $-5.67^{* *}$ & $0.11^{*}$ & $0.16^{* *}$ & $3.40^{* *}$ & $0.16^{\text {** }}$ & $1.70^{* *}$ & $46.15^{* *}$ \\
\hline & $\mathrm{F}_{2}$ & 0.98 & $24.55^{*}$ & $-0.16^{* *}$ & $-6.70^{* *}$ & -0.05 & -0.07 & 1.23 & -0.04 & 0.68 & 18.91 \\
\hline \multirow{3}{*}{ DH19 } & Mean & 25.50 & 510.89 & 17.90 & 111.90 & 10.22 & 2.59 & 44.57 & 1.77 & 68.53 & 632.58 \\
\hline & $\mathrm{F}_{1}$ & -1.71 & -5.17 & $0.40^{*}$ & $7.02^{* *}$ & $0.10^{*}$ & $-0.09^{* *}$ & 0.55 & $-0.09^{* *}$ & -0.74 & $-24.97^{* *}$ \\
\hline & $\mathrm{F}_{2}$ & $-2.93^{*}$ & -17.52 & $-0.12^{*}$ & 2.23 & $0.37^{*}$ & 0.10 & $3.71^{* * *}$ & 0.08 & 0.51 & $34.45^{*}$ \\
\hline \multirow{3}{*}{ DH20 } & Mean & 29.27 & 582.28 & 17.92 & 110.02 & 10.27 & 3.01 & 38.54 & 1.96 & 65.00 & 624.06 \\
\hline & $\mathrm{F}_{1}$ & -0.7 & -13.04 & -0.29 & $4.55^{* *}$ & $-0.27^{* *}$ & $0.09^{* *}$ & $-2.83^{* *}$ & $0.08^{* *}$ & 0.68 & $21.35^{* *}$ \\
\hline & $\mathrm{F}_{2}$ & 0.99 & $54.26^{* *}$ & $-0.11^{*}$ & $4.58^{* *}$ & -0.06 & 0.12 & -0.57 & $0.11^{*}$ & 0.51 & 40.74 \\
\hline \multirow{3}{*}{ DH21 } & Mean & 28.18 & 468.03 & 18.10 & 109.75 & 11.31 & 2.89 & 45.65 & 2.09 & 72.26 & 554.41 \\
\hline & $\mathrm{F}_{1}$ & 1.11 & -23.25 & $0.47^{* *}$ & $-1.05^{*}$ & $0.38^{* *}$ & $-0.05^{*}$ & $-1.06^{* *}$ & -0.03 & 0.47 & -7.24 \\
\hline & $\mathrm{F}_{2}$ & -1.57 & -17.6 & $-0.27^{* *}$ & 2.04 & $0.59^{* *}$ & 0.04 & 0.05 & 0.02 & -0.37 & -2.08 \\
\hline \multirow{3}{*}{ DH-22 } & Mean & 22.46 & 488.45 & 18.17 & 106.05 & 10.44 & 2.58 & 40.22 & 1.74 & 67.75 & 520.91 \\
\hline & $\mathrm{F}_{1}$ & -2.22 & -5.96 & $-0.40^{*}$ & $1.32^{* *}$ & -0.10 & $-0.19^{* *}$ & $-5.14^{* *}$ & $-0.25^{* *}$ & $-4.04^{* *}$ & $-68.86^{* *}$ \\
\hline & $\mathrm{F}_{2}$ & -0.93 & $-36.55^{* *}$ & $-0.19^{* *}$ & $-3.70^{* *}$ & -0.04 & -0.02 & -1.19 & -0.04 & -1.11 & $-33.66^{*}$ \\
\hline \multirow{2}{*}{ SE } & $\overline{F_{1}}$ & 1.39 & 13.53 & 0.17 & 0.46 & 0.05 & 0.02 & 0.31 & 0.02 & 0.55 & 5.60 \\
\hline & $\mathrm{F}_{2}$ & 1.33 & 9.77 & 0.05 & 1.34 & 0.15 & 0.07 & 1.25 & 0.05 & 0.92 & 13.46 \\
\hline \multicolumn{12}{|l|}{ Testers } \\
\hline \multirow{3}{*}{ Altay-2000 } & Mean & 26.86 & 463.00 & 18.49 & 107.10 & 10.52 & 2.33 & 44.40 & 1.53 & 65.36 & 487.63 \\
\hline & $\mathrm{F}_{1}$ & $-2.33^{*}$ & -19.06 & $0.74^{* *}$ & $2.07^{* *}$ & $-0.15^{* *}$ & $-0.19^{* *}$ & $-3.53^{* *}$ & $-0.17^{* *}$ & $-1.33^{* *}$ & $-47.87^{* *}$ \\
\hline & $\mathrm{F}_{2}$ & -1.6 & $-32.98^{* *}$ & $0.22^{* *}$ & $3.98^{* *}$ & -0.10 & 0.03 & 0.43 & -0.03 & $-1.83^{*}$ & $-24.96^{*}$ \\
\hline \multirow{3}{*}{ Bezostaja-1 } & Mean & 30.61 & 508.84 & 19.05 & 110.57 & 10.84 & 2.53 & 48.34 & 2.01 & 80.82 & 483.29 \\
\hline & $\mathrm{F}_{1}$ & 0.54 & 3.29 & 0.03 & $2.09^{* *}$ & 0.02 & $0.10^{* *}$ & $1.87^{* *}$ & $0.14^{* *}$ & $2.44^{* *}$ & $38.99^{* *}$ \\
\hline & $\mathrm{F}_{2}$ & 2.12 & -1.85 & $-0.14^{* *}$ & $2.92^{* *}$ & -0.05 & -0.06 & -1.98 & -0.04 & 0.38 & -17.80 \\
\hline \multirow{3}{*}{ Harmankaya-99 } & Mean & 29.84 & 517.61 & 18.81 & 107.04 & 10.60 & 3.07 & 54.12 & 2.20 & 71.81 & 621.66 \\
\hline & $\mathrm{F}_{1}$ & $2.98^{* *}$ & 10.3 & -0.15 & $-0.72^{*}$ & -0.07 & $0.14^{* *}$ & -0.24 & $0.08^{* *}$ & -0.48 & $23.01^{* *}$ \\
\hline & $\mathrm{F}_{2}$ & 0.79 & $17.01^{*}$ & -0.04 & $-4.39^{* *}$ & 0.01 & $0.16^{* *}$ & $2.31^{*}$ & $0.14^{\text {*** }}$ & 0.75 & $50.34^{* *}$ \\
\hline \multirow{3}{*}{ Kate A-1 } & Mean & 20.05 & 520.78 & 17.53 & 92.52 & 10.02 & 2.36 & 52.97 & 1.68 & 71.04 & 573.97 \\
\hline & $\mathrm{F}_{1}$ & -1.19 & 5.46 & $-0.62^{* *}$ & $-3.45^{* *}$ & $0.20^{* *}$ & $-0.05^{*}$ & $1.90^{* *}$ & $-0.05^{* *}$ & -0.62 & $-14.13^{* *}$ \\
\hline & $\mathrm{F}_{2}$ & -1.31 & $17.83^{*}$ & -0.04 & $-2.51^{*}$ & 0.14 & $-0.13^{*}$ & -0.76 & $-0.08^{*}$ & 0.70 & -7.58 \\
\hline \multirow{2}{*}{ SE } & $\mathrm{F}_{1}$ & 1.05 & 10.23 & 0.13 & 0.35 & 0.04 & 0.04 & 0.23 & 0.01 & 0.41 & 4.23 \\
\hline & $\mathrm{F}_{2}$ & 1.01 & 7.38 & 0.03 & 1.01 & 0.11 & 0.13 & 0.94 & 0.04 & 0.70 & 10.18 \\
\hline
\end{tabular}

${ }^{*} \mathrm{P}<0.05,{ }^{* *} \mathrm{P}<0.01$ (FLA: Flag leaf area; FLCC: Flag leaf chlorophyll content; CT: Canopy temperature; PH: Plant height; SL: Spike length; SW: Spike weight; KNS: Kernel number per spike; KWS: Kernel weight per spike; SHI: Spike harvest index; GY: Grain yield) 
The negative GCA effects were generally observed for canopy temperature (Table 2). There is a direct relationship between the change in canopy temperature and grain yield in stress conditions (Reynolds et al., 2001). The differences of canopy temperature are a result of drought stress and response to temperature and low canopy temperature is desirable (McKinney et al., 1989). Majority of negative GCA effects in the examined population indicated that gene effects decreasing the canopy temperature were dominant. Genotypes with negative GCA (especially DH20, DH22, Harmankaya-99 and Kate A-1) were desirable parents for low canopy temperature. Genotypes DH16 and Harmankaya-99 showed positive and significant GCA for flag leaf area; this indicates that their combinations may be relatively large leaves. There were not statistically significant GCA values in the $F_{1}$ generation for flag leaf chlorophyll content. The GCA effects of the Altay-2000 and DH22 genotypes were significant negative direction while DH18, Kate A-1, Harmankaya-99 and DH20 genotypes showed positive and significant GCA effects in the $F_{2}$ generation (Table 2). High chlorophyll is a desirable property for more photosynthesis and high yield. However, genotypes and generations have negative combination value may be important to improve appropriate cultivars for extreme hot and dry areas, because the genotypes containing high chlorophyll have high canopy temperature (Reynolds et al., 2001).

Regarding plant height, DH6, DH18, Harmankaya-99 and Kate A-1 showed a negative GCA effect in both generations. In addition, the GCA effects of DH21 in the $\mathrm{F}_{1}$ generation and $\mathrm{DH} 22$ in $\mathrm{F}_{2}$ generation were the negative direction. These parents could be used as parents to develop a shorter variety. Bread wheat varieties with short or medium height have a prominent place in breeding programs because they have lodging resistance and high yield. However, excessive shortening in plant height adversely affects the suitability of harvest with a machine, the area of photosynthesis and the adaptation to barren conditions (Altinkut et al., 2001). It is known that short varieties are more yielding especially for irrigated areas and tall cultivars are more proper for arid-marginal areas. Altay-2000, Bezostaja-1 and DH20 can be used as parent in breeding programs for tallness. Because the increase in spike length is a factor affecting the number of spikelets and the number of kernel in the spike, it can be used as a morphological selection criterion. It may be appropriate to keep the DH19 and DH21 lines as a parent in breeding programs because of their positive and significant GCA values in both generations. Genotypes DH6, DH16 and Bezostaja-1 with a positive GCA value should be noted as a parent to increase in spike weight, kernel number per spike, kernel weight per spike and spike harvest index, because these properties will directly affect the yield. GCA values were found to between 68.86 (DH22) and 94.03 (DH6) in $\mathrm{F}_{1}$ generation, and in $\mathrm{F}_{2}$ -37.01 (DH16) to 50.34 (Harmankaya-99) for grain yield (Table 2). Using parents with high GCA value may be facilitate the selection of early generation in a breeding study. Genotypes such as Harmankaya-99 and DH20, especially with positive and significant GCA, can be considered as appropriate parents to increase grain yield.

\section{Heterotic grouping based on specific combining ability and hybrid performance}

It is desirable to regulate germplasm by $\mathrm{HG}$ for an effective breeding program (Reif et al., 2007). The HG can be easily evaluated by selecting representative genotypes from each identified subgroup based on geographical origin, morphological data, pedigree information and breeding history or molecular marker. Eventually, hybrids between these genotypes in field trials are evaluated by selecting $\mathrm{HG}$ based on hybrid performance or components, i.e. Ht and high observation values (Melchinger, 1999). Different methods have been developed to create HG. Determining the appropriate method will depend on the genetic structure of the genotypes involved in HG. Some criteria have been proposed to select HG depending on the SCA, such as high average performance in the hybrid population, large genetic variance, high transferability of superior performance of parents to offspring and grater SCA variance than GCA (Reif et al., 2005). In this study, the SCA variance of the examined properties was higher than the GCA variance. Therefore, it could be possible to create the SCA-based HG. The hybrids were classified into $5 \mathrm{HG}$ in the $\mathrm{F}_{1}$ generation and 6 in the $\mathrm{F}_{2}$ generation according to the yield-SCA data (Figure 1). Twelve of the hybrids took part in the same $H G$ in both $F_{1}$ and $F_{2}$. Superior combinations can be created in terms of high variation and desired properties with the hybridization between the members of the different groups in $F_{1}$ and $F_{2}$. Especially, the DH lines obtained from these combinations should be taken into account to create new hybrids.

The means, SCA, Ht and $\mathrm{Hb}$ values of hybrids for the traits were evaluated in $\mathrm{HG}$ (Table 3). Although the highest mean value for the flag leaf area was observed in the HG-3 group in $F_{1}$ generation, the SCA value was negative, and the $\mathrm{Ht}-\mathrm{Hb}$ values were lower than $\mathrm{HG}-1$ and HG-2. In the $F_{2}$ generation, the hybrids with the highest values were collected in HG-4. Hybrids in these groups can be followed as promising for flag leaf area. The "DH20×Harmankaya-99" should be particularly emphasized due to the good performance in both generations. When HG was examined in terms of flag leaf chlorophyll content, it was seen that genotypes with highest values were found in HG-4 and HG-1. In the $F_{1}$ generation, HG-4 member "DH22 $\times$ Altay-2000" and "DH $22 \times$ Kate A-1" with the highest values lost their performance in $\mathrm{F}_{2}$ generation. The "DH6×Altay-2000" was genotypes within high-valued group in both generations. Therefore it should be considered as promising for this feature (Table 3, Figure 1). Since low canopy temperature is desirable, low valued genotypes should be taken account for the trait. The "DH22×Bezostaja-1", in HG-5 $\left(\mathrm{F}_{1}\right)$ and HG-6 $\left(\mathrm{F}_{2}\right)$, should be particularly emphasized. When the $\mathrm{HG}$ was examined for plant height and spike length, it was observed that the population was proper to make selection for tallness due 
to the high means and positive $\mathrm{Ht}$ and $\mathrm{Hb}$ value. Additionally, positive and negative values of SCA effects indicated that there was sufficient variation for these two traits in this population. "DH6 $\times$ Altay-2000" and "DH22×Altay-2000" hybrids were should be considered for tallness as promising combinations.

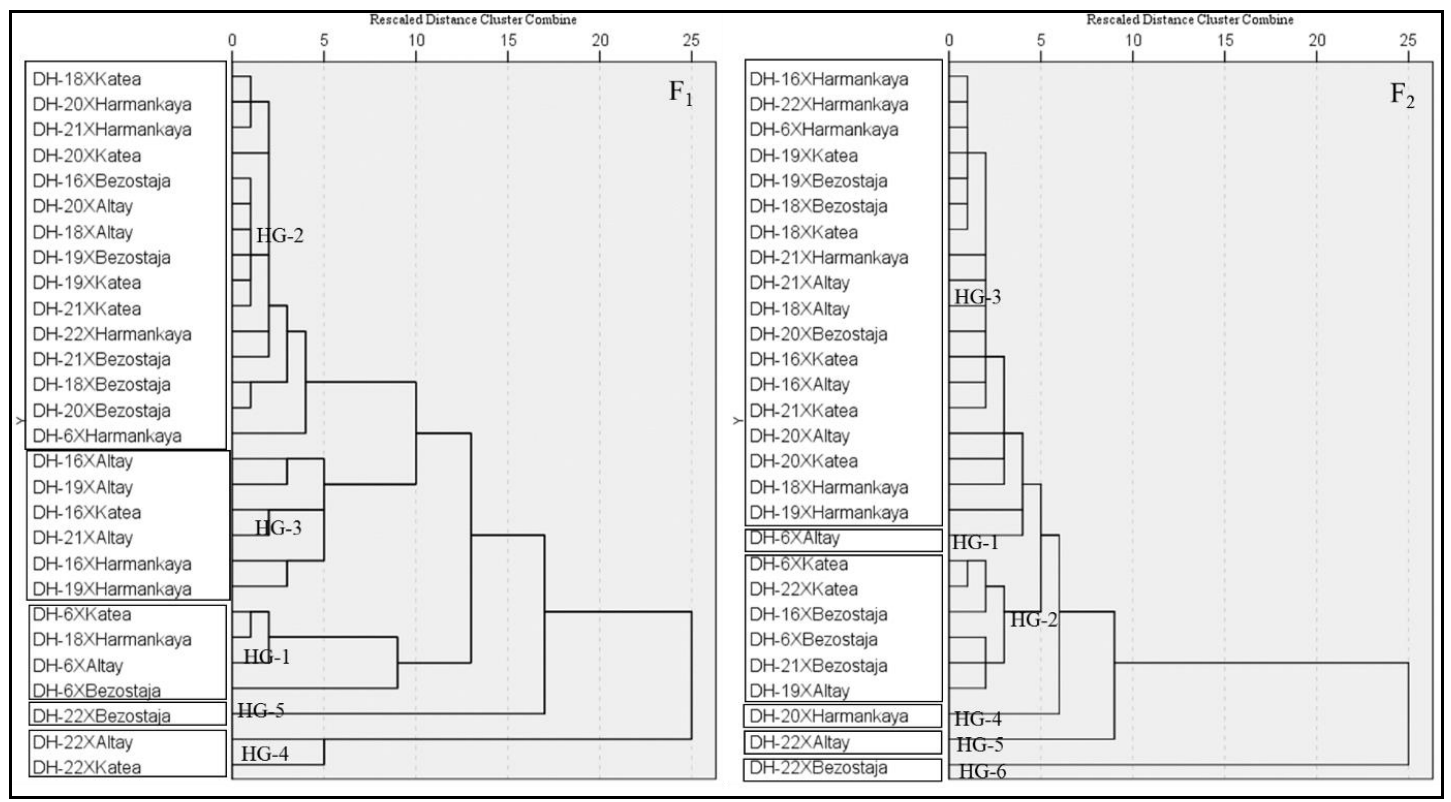

Figure 1. Dendrogram showing heterotic grouping based on the specific combining ability of hybrids.

The positive $\mathrm{SCA}, \mathrm{Ht}$ and $\mathrm{Hb}$ in $\mathrm{F}_{1}$ indicated that there was a dominance increasing in spike characteristics, directly affecting the yield, in these populations. HG-1 included high mean values, SCA and Ht in terms of spike characteristics in both generations (Table 3). Heterosis is very important for hybrid breeding and population improvement programs in self-pollinated plants. Parental and hybrid combinations with high $\mathrm{Ht}$ are likely to maintain these forces in cases where non-additive gene effects are important. However, heterotic effect in the subsequent generations may be lost when dominant gene effects are effective in the inheritance of the studied feature. Many researchers have reported high SCA, Ht and $\mathrm{Hb}$ values for these characteristics (Ahmad et al., 2017; Ferrari et al., 2018; Rajput and Kandalkar, 2018). While $\mathrm{Ht}$ of spike harvest index was positive in all groups in $\mathrm{F}_{1}$, $\mathrm{Ht}-\mathrm{Hb}$ values were lower and negative in $\mathrm{F}_{2}$ generation due to the decrease of heterozygosity. It would be appropriate to follow up combinations with high phenotypic values, high and positive $\mathrm{Ht}-\mathrm{Hb}$ values and positive SCA effects as promising hybrids in both generations such as "DH6×Altay-2000", "DH16×Bezostaja-1, "DH20×Harmankaya-99", "DH21×Bezostaja-1", and "DH22×Bezostaja-1" for spike characteristics. Hybrids with the highest yield in $F_{1}$ were collected in the same group (HG-1), and these hybrids also had positive SCA effect and Ht-Hb values. HG-5 with a single-member was taken part in the second in terms of average yield, while it's SCA effect, $\mathrm{Ht}$ and $\mathrm{Hb}$ values were the highest within groups. The four of HG was single-member in the $F_{2}$ generation and "DH22 $\times$ Bezostaja-1" in HG-6 was the highest yield, $\mathrm{SCA}, \mathrm{Ht}$ and $\mathrm{Hb}$ values in both generations (Table 4, Figure 1), so it followed for high yield as a promising hybrid.

As a result of clustering analysis based on morphological data of the parents four group were clustered (Figure 2). The presences of intra-group and inter-group variations showed that these genotypes were suitable parents to improve the examined properties. The distances between the groups varied between 58.65 ( $\mathrm{C} 1$ $\mathrm{C} 4)$ and 155.12 (C1-C2). The maximum intra-group distance was calculated for the C-3 group, followed by the C-2 (Figure 3). The combinations of Kate A-1 with lines in $\mathrm{C}-3$ were hybrids with moderately high values (Figure 2, Table 3). The combinations of $\mathrm{C} 1$ with $\mathrm{C} 2$ hybridization were found in high-valued groups and these superior properties were observed in both generations. Some of the combinations from crosses between $\mathrm{C} 1$ and $\mathrm{C} 4$ were in the same group as the high-value hybrids (Figure 1 and 2, Table 3). 
Table 3. Means of observation, specific combining ability, heterosis and heterobeltiosis values in heterotic groups for examined traits.

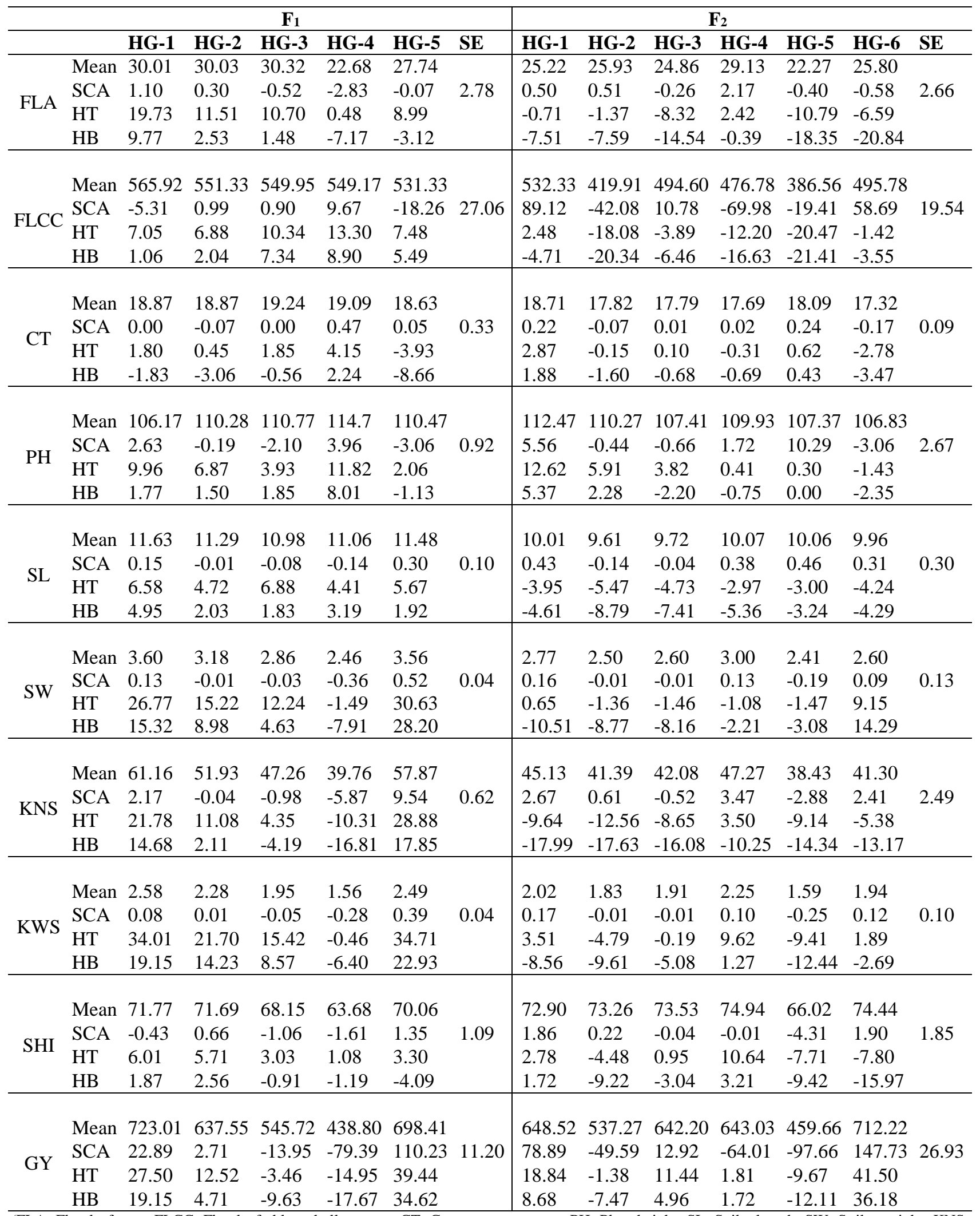

(FLA: Flag leaf area; FLCC: Flag leaf chlorophyll content; CT: Canopy temperature; PH: Plant height; SL: Spike length, SW: Spike weight; KNS: Kernel number per spike; KWS: Kernel weight per spike; SHI: Spike harvest index; GY: Grain yield) 
Table 4. Inter-group and intra-group distances of heterotic groups generated according to yield based-SCA values

\begin{tabular}{|c|c|c|c|c|c|c|c|}
\hline & & HG-1 & HG-2 & HG-3 & HG-4 & HG-5 & \\
\hline \multirow{5}{*}{$\mathrm{F}_{1}$} & HG-1 & 43.45 & 90.245 & 185.950 & 307.230 & 92.814 & \\
\hline & HG-2 & & 72.23 & 95.768 & 217.930 & 129.932 & \\
\hline & HG-3 & & & 40.74 & 126.127 & 206.239 & \\
\hline & HG-4 & & & & 18.69 & 330.211 & \\
\hline & HG-5 & & & & & 0 & \\
\hline \multirow{7}{*}{$\mathrm{F}_{2}$} & & HG-1 & HG-2 & HG-3 & HG-4 & HG-5 & HG-6 \\
\hline & HG-1 & 0 & 171.913 & 66.783 & 144.187 & 260.926 & 100.333 \\
\hline & HG-2 & & 36.00 & 123.441 & 107.181 & 91.781 & 270.719 \\
\hline & HG-3 & & & 102.78 & 77.610 & 215.143 & 157.968 \\
\hline & HG-4 & & & & 0 & 187.296 & 228.880 \\
\hline & HG-5 & & & & & 0 & 359.101 \\
\hline & HG-6 & & & & & & 0 \\
\hline
\end{tabular}

${ }^{*}$ The numbers shown in italics and bold are the distance within the group

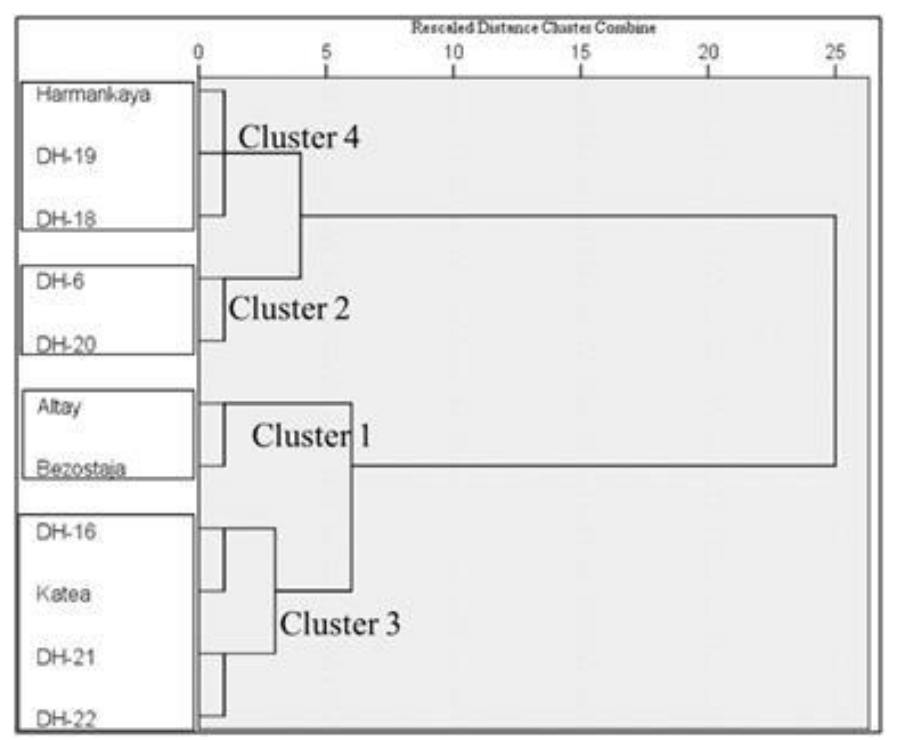

Figure 2. Dendogram of eleven parents calculated based on morphological data using Euclidean distance matrix.

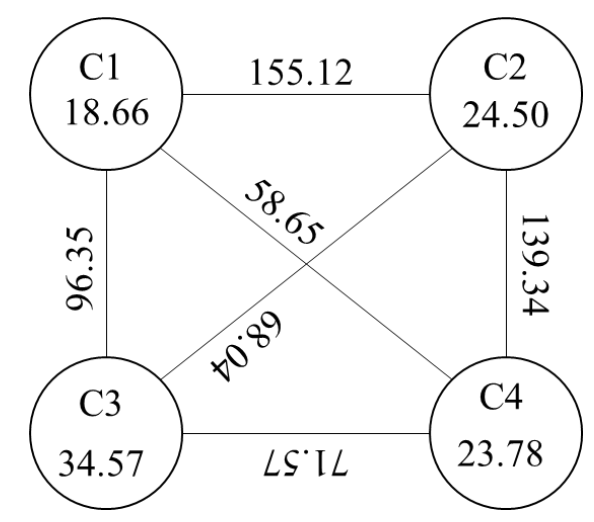

Figure 3. Cluster diagram showing inter-group and intra-group distances

The parents of "DH6×Altay-2000" and heterozygosity, Ht and yield stability of new varieties (Fan "DH22×Bezostaja-1" hybrids performed well in both et al., 2009; Esposito et al., 2013; Pandey et al., 2015; generations were in different clusters with the most distant Akel et al., 2018). The different allelic combinations of (Figure 2 and 3). Hybridization between genotypes with specific loci in each parent probably appear as $\mathrm{Ht}$ different HG will increase the genetic variation, expressions in their hybrids (Pandey et al., 2015). Namely, 
hybridization of genetically distant parents in terms of morphological features will result in high Ht. However, Singh and Ramanujam (1981) argued that parents in the same group might also have a very high $\mathrm{Ht}$ value because of irrelevance between genetic diversity and $\mathrm{Ht}$. The values of inter-group and intra-group distances of the heterotic groups formed by the hybrids presented in Table 4 support this view.

In conclusion, the DH18, DH20 and Harmankaya-99 were good combiner and "DH6 $\times$ Kate A-1", "DH16×Altay-2000", "DH16×Kate A-1", "DH18×Bezostaja-1", "DH21×Kate A-1", and "DH22×Bezostaja-1" were the best hybrids for the physiological, morphological and yield-related plant characteristics. The prominent of non-additive gene effects clearly put forth that selection of excellent plants should be postponed to $\mathrm{F}_{4}$ or $\mathrm{F}_{5}$ generations for the studied traits. Maybe, the genetic distance between the genotypes may need to be supported molecular markers evaluation. However, it will be just a complementary outcome. Therefore, gained results were pointed out that a useful tool the HG based on SCA for future breeding studies.

\section{ACKNOWLEDGEMENTS}

This study was supported by Scientific Research Commission of Eskisehir Osmangazi University (Project no: 201723009).

\section{LITERATURE CITED}

Abdel, Nour, N.A.R., H. S. A. El-Fateh and A. K. Mostafa. 2011. Line $\times$ tester analysis for yield and its traits in bread wheat. Egypt. J. Agric. Res. 89 (3): 979-992.

Acquaah, G. 2012. Principles of Plant Genetics and Breeding. Second edition, John Wiley and Sons, UK.

Ahmad, E., M. Akhtar, S. Badoni and J. P. Jaiswal. 2017. Combining ability studies for seed yield related attributes and quality parameters in bread wheat Triticum aestivum L.. Journal of Genetics Genomics and Plant Breeding, 1: 2127.

Akel, W., P. Thorwarth, V. Mirdita, E. A. Weissman, G. Liu, T. Würschum and C. F. H. Longin. 2018. Can spelt wheat be used as heterotic group for hybrid wheat breeding?. Theoretical and Applied Genetics 131 (4): 973984.

Altinkut, A., K. Kazan, Z. Ipekci and N. Gozukirmizi. 2001. Tolerance to paraquat is correlated with the traits associated with water stress tolerance in segregating $\mathrm{F}_{2}$ populations of barley and wheat. Euphytica 121:81-86.

Anderberg, M. R. 1993. Cluster Analysis for Application. Academic press, New York.

Aslam, R., M. Munawar and A. Salam. 2014. Genetic architecture of yield components accessed through line $\times$ tester analysis in wheat (Triticum aestivum L.). Universal Journal of Plant Science 2(5): 93-96.

Aytac, Z. and G. Kinaci. 2009. Genetic variability and association studies of some quantitative characters in winter rapeseed Brassica napus L. African Journal of Biotechnology 8 (15): 3547-3554.

Barot, H. G., M. S. Patel, W. A. Sheikh, L. P. Patel and C. R. Allam 2014. Heterosis and combining ability analysis for yield and its component traits in wheat (Triticum aestivum L.). Electronic Journal of Plant Breeding 5(3): 350-359.

Beena, R., V. Vighneswaran, P. Sindhumole, M.
Narayankutty and S. R. Voleti. 2018. Impact of high temperature stress during reproductive and grain filling stage in rice. ORYZA-An International Journal on Rice 551: 126133.

Cochran, W. G. and M. C. Cox 1957. Experimental Design. John Wiley and Sons, Inc. New York.

Esposito, M. A., H. Gatti, V. P. Cravero, F. S. L. Anodo and E. L. Cointry. 2013. Combining ability and heterotic groups in Pea. Aust. J. Crop Sc. 11: 1634- 1641.

Falconer, D. S. and T. F. C. Mackay 1996. Introduction to Quantitative Genetics. Longman, $464 \mathrm{p}$.

Fan, X. M., Y. M. Zhang, W. H. Yao, H. M. Chen, J. Tan, C. X. Xu, X. L. Han, L. M. Luo and M. S. Kang. 2009. Classifying maize inbred lines into heterotic groups using a factorial mating design. Agron. J. 101: 106-112.

Ferrari, E., A. Picca, R. Domínguez and H. Paccapelo. 2018. Heterosis and combining ability for yield and other agronomic traits in Triticale. Open Agriculture 31: 38-45.

Flood, P. J., J. Harbinson and M. G. Aarts 2011. Natural genetic variation in plant photosynthesis. Trends in Plant Science 166: 327-335.

Fonseca, S. M. and F. L. Patterson. 1968. Hybrid vigor in a seven parent diallel cross in common winter wheat Triticum aestivum L.. Crop. Sci. 8: 85-88.

Goldringer, I., P. Brabant and A. Gallais. 1997. Estimation of additive and epistatic genetic variances for agronomic traits in a population of doubled-haploid lines of wheat. Heredity 79(1): 60-71.

Hannachi, A., Z. A. Fellahi, H. Bouzerzour and A. Boutakrabt. 2013. Diallel-cross analysis of grain yield and stress tolerance-related traits under semi-arid conditions in durum wheat (Triticum durum Desf.). Electronic Journal of Plant Breeding 41: 1027-1033.

Hill, W. G. 2010. Understanding and using quantitative genetic variation. Philosophical Transactions of the Royal Society of London B: Biological Sciences 3651537: 73-85.

Istipliler, D., E. Ilker, F. A. Tonk, G. Civi and M. Tosun. 2015. Line $\times$ tester analysis and estimating combining abilities for yield and some yield components in bread wheat. Turk. J. Field Crops 201: 72-77.

Jackson, P., M. Robertson, M. Cooper and G. Hammer. 1996. The role of physiological understanding in plant breeding, from a breeding perspective. Field Crops Res. 49: 11-37.

Kalayci, M., V. Ozbek, C. Cekic, H. Ekiz, M. Keser and F. Altay. 1998. Determination of Drought Resistant Wheat Genotypes and Development of Morphological and Physiological Parameters in Central Anatolia Conditions, Eskisehir, Tubitak Research Project Final Report. Anatolian Agricultural Research Institute (in Turkish).

Kempthorne, O. 1957. An Introduction to Genetic Studies. John Wiley and Sons Inc., New York. pp. 265-270.

Krystkowiak, K., T. Adamski, M. Surma and Z. Kaczmarek. 2009. Relationship between phenotypic and genetic diversity of parental genotypes and the specific combining ability and heterosis effects in wheat Triticum aestivum L. Euphytica 1653: 419-434.

Kutlu, I. and M. Olgun. 2015. Determination of genetic parameters for yield components in bread wheat. Int. J. Bioscience 612: 61-70.

McKinney, N. V., J. R. Schapaugh and E. T. Kanemasu. 1989. Selecting for canopy temperature differential in six populations of soybean. Crop Sci. 29: 255-259.

Melchinger, A. E. 1999. Genetic diversity and heterosis. In: The Genetics and Exploitation of Heterosis in Crops. Ed. Coors, J. G. and S. Pandey. ASA, CSSA, and SSSA, Madison, WI. pp. $99-118$.

Novoselovic, D., M. Baric, G. Drezner, J. Gunjaca and A. Lalic. 
2004. Quantitative inheritance of some wheat plant traits. Genetics and Molecular Biology 27(1): 92-98.

Ozcan, K. and N. Acikgoz. 1999. Development of a statistical package program for population genetics. In: Third Symposium on Computer Applications in Agriculture, Adana, Turkey.

Pandey, P., V. R. Pandey, A. Kumar, S. Yadav, D. Tiwari and R. Kumar. 2015. Relationship between heterosis and genetic diversity in Indian pigeonpea [Cajanus cajan L. Millspaugh] accessions using multivariate cluster analysis and heterotic grouping, Australian Journal of Crop Science 96: 494.

Rad, M. R. N., M. A. Kadir and M. R. Yusop. 2012. Genetic behaviour for plant capacity to produce chlorophyll in wheat (Triticum aestivum L). Australian Journal of Crop Science 63: 415-420.

Rajput, R. S. and V. S. Kandalkar. 2018. Combining ability and heterosis for grain yield and its attributing traits in bread wheat (Triticum aestivum L). Journal of Pharmacognosy and Phytochemistry 72: 113-119.

Reif, J. C., A. R. Hallauer and A. E. Melchinger. 2005. Heterosis and heterotic pattern in maize. Maydica 50: 215-223.

Reif, J. C., F. M. Gumpert, S. Fischer and A. E. Melchinger. 2007. Impact of inter population divergence on additive and dominance variance in hybrid populations. Genetics 176: 1931-1934.

Reynolds, M. P., S. Nagarajan, M. A. Razzaque and O. A. A. Ageeb. 2001. Heat tolerance. In: Application of Physiology in Wheat Breeding. Ed. Reynolds, M. P. CIMMYT.

Riday, H., E. C. Brummer, T. A. Campbell, D. Luth and P. M. Cazcarro. 2003. Comparisons of genetic and orphological distance with heterosis between Medicago sativa subsp. sativa and subsp. Falcate. Theor. Appl. Genet. 131: 37-45.

Saeed, M., I. H. Khalil, D. Nayab, S. A. Anjum and M. Tanveer. 2016. Combining ability and heritability for yield traits in wheat (Triticum aestivum L). Pak. J. Agric. Sci. 533: 577583.

Saeed, M. and I. H. Khalil. 2017. Combining ability and narrowsense heritability in wheat (Triticum aestivum L.) under rainfed environment. Sarhad Journal of Agriculture 331: 2229.

Singh, S. P. and S. Ramanujam 1981. Genetic divergence and hybrid performance in Cicer arietinum L. Indian J. Genet. 41: $268-276$.

Singh, T. P., J. Kumari, R. Yadav and P. Prakesh. 2017. Effect of drought and high temperature on physiological traits and wheat production. Advances in Plant Physiology 15: 147.

Tecklewold, A. and H. C. Becker. 2006. Comparison of phenotypic and molecular distances to predict heterosis and $\mathrm{F}_{1}$ performance in Ethiopian Mustard Brassica carinata A. Braun. Theor. Appl. Genet. 112: 752-759.

Wenkel, K. O., S. Brozio, R. Gebbers and W. Mirschel. 2003. Approaches to site-specific nitrogen fertilization. Archives of Agronomy and Soil Science 492: 149-162.

Yildirim, M., C. Akinci, M. Koc and C. Barutcular. 2009. Applicability of canopy temperature depression and chlorophyll content in durum wheat breeding. Anadolu J. Agric. Sci. 243: 158-166.

Yildirim, M., M. Koc, C. Akinci and C. Barutcular. 2013. Variations in morphological and physiological traits of bread wheat diallel crosses under timely and late sowing conditions. Field Crops Research 140: 9-17. 